\title{
Institutional Variables Affecting Female Representation in National Legislatures: The Case of Norway
}

\author{
Richard E. Matland \\ The Journal of Politics, Vol. 55, No. 3. (Aug., 1993), pp. 737-755.
}

Stable URL:

http://links.jstor.org/sici?sici=0022-3816\%28199308\%2955\%3A3\%3C737\%3AIVAFRI\%3E2.0.CO\%3B2-2

The Journal of Politics is currently published by Southern Political Science Association.

Your use of the JSTOR archive indicates your acceptance of JSTOR's Terms and Conditions of Use, available at http://www.jstor.org/about/terms.html. JSTOR's Terms and Conditions of Use provides, in part, that unless you have obtained prior permission, you may not download an entire issue of a journal or multiple copies of articles, and you may use content in the JSTOR archive only for your personal, non-commercial use.

Please contact the publisher regarding any further use of this work. Publisher contact information may be obtained at http://www.jstor.org/journals/spsa.html.

Each copy of any part of a JSTOR transmission must contain the same copyright notice that appears on the screen or printed page of such transmission.

The JSTOR Archive is a trusted digital repository providing for long-term preservation and access to leading academic journals and scholarly literature from around the world. The Archive is supported by libraries, scholarly societies, publishers, and foundations. It is an initiative of JSTOR, a not-for-profit organization with a mission to help the scholarly community take advantage of advances in technology. For more information regarding JSTOR, please contact support@jstor.org. 


\title{
Institutional Variables Affecting Female Representation in National Legislatures: The Case of Norway
}

\author{
Richard E. Matland \\ University of Houston
}

A controversy exists over whether district magnitude, the number of seats per district, has a positive effect on female representation. This study considers district magnitude's effect on female representation in Norway over a 40 -year period. The data analysis finds that party magnitude, the size of a party's district delegation, is a more powerful explanatory factor than district magnitude. Party magnitude's effect appears to follow a cycle. Prior to demands for representation being raised, party magnitude has little effect. As women mobilize and representation demands are raised party magnitude plays a significant role, but once women are firmly entrenched as powerful players in party politics, party magnitude's effect decreases. This formulation is consistent with the Norwegian findings and also explains why previous cross-sectional research has produced inconsistent findings. In addition, the crucial role that candidate nomination processes play in explaining the high levels of representation found in Norway is described.

W

omen are greatly underrepresented in national legislatures throughout the world. ${ }^{1}$ In 1992, the Inter-Parliamentary Union estimated that only $11 \%$ of the legislators in its 144 member countries were women. There is, however, substantial variation across countries. The United States at $10 \%$ and United Kingdom at $9 \%$ are below the international average, while Finland (39\%) and Norway $(36 \%)$ have the highest levels of representation. Recent research aimed at explaining underrepresentation and variations in representation of women has concentrated on three basic categories of explanations: cultural, socioeconomic, and institutional factors.

This article concentrates on institutional factors. Researchers increasingly have turned to institutional factors as important determinants of female representation (Darcy, Welch, and Clark 1987). This has coincided with a general increase in research on the political effects of electoral institutions (Grofman and Lijphart 1986;

'I would like to thank the American Scandinavian Foundation, the Norwegian Marshall Fund, and the University of Houston for financially supporting this research. I would like to thank Bernt Aardal, Mark Franklin, Bruce Oppenheimer, and Wilma Rule for comments on earlier versions of the paper. Finally, I would like to thank the Norwegian Research Centre in Organization and Management for providing a hospitable and collegial environment in which to work on this research while I was in Norway. 
Lijphart 1985; and Taagepera and Shugart 1989). Emphasis on institutional factors are caused both by their substantive importance in understanding representation processes and their significance from a policy perspective. Institutional arrangements, unlike most cultural and socioeconomic factors, are pliable. Conclusive findings of an institutional arrangement's effect can lead to policy proposals for changing institutions in order to produce a desired outcome.

Work on institutional explanations for variations in female representation has concentrated on electoral systems. Most of the early work emphasized the differences between proportional representation (PR) and single-member district systems (Castles 1981; Duverger 1955; Lakeman 1976; Norris 1985; Rule 1981). This research documents that PR systems are associated with higher levels of representation for women. More recently other institutional factors have come under scrutiny. Two electoral institutions are discussed: district magnitude, the number of seats per district, and candidate nomination processes. District magnitude has been a subject of controversy as previous research findings provide contradictory results. Districts magnitude's effect in Norway is analyzed over a 40 -year period. Further consideration of the Norwegian case leads to the conclusion that candidate nomination procedures are pivotal to explaining Norway's high levels of representation. After dealing with district magnitude, the paper goes on to describe how candidate nomination procedures affect women's representation.

\section{District MaGNitude}

Most of the theoretical arguments for why district magnitude should have a positive effect on female representation are closely related to the assumption that as district magnitude increases, election strategies change. Contests in singlemember districts are by definition zero-sum games. Multimember districts, while fixed-sum games, are not zero-sum games, and this can affect party officials, candidates, and voters.

Increases in districts magnitude should make it easier for party officials to slate women candidates for two reasons. First, the party may see slating women as essential to its appeal to voters. As district magnitude increases, the exclusion of women from the party's list of candidates becomes increasingly obvious and increases the danger of a negative reaction from voters. Second, within the party, it is easier to slate women in districts with large magnitudes. If district magnitude is one, there is a zero-sum context within the party; by slating a female candidate all male candidates are shut out. With a larger magnitude, men who represent powerful intraparty constituencies do not need to be deposed in order for a woman to receive a spot on the party's list. Balancing the ticket is possible when district magnitude is large; it is more difficult when district magnitude is small.

The non-zero sum nature of multimember district elections allows candidates to concentrate on winning votes for themselves and provides correspondingly less 
emphasis on attacking one's opponent. To the degree Kirkpatrick's (1974) assertion that women prefer to highlight their own strengths rather than denigrate their opponents is true, women should be more interested in running in multimember districts.

Voters may also react to these distinctions. Voters who might be hesitant to vote for a woman as their only representative may be more willing to vote for a woman as one of many candidates. While this is unlikely to be the attitude of a large number of voters, even a few percentage points can influence election outcomes.

District magnitude could also have a positive effect on female representation if larger districts are associated with greater turnover. If social or institutional conditions change so that women who were previously discriminated against are now competing on a level playing field, low turnover rates can serve as an anchor impeding change and keeping representation rates unnecessarily low. Districts with many representatives lead to diminished visibility for each individual representative. Multimember district representatives also tend to do less constituency work than single-member district representatives (Jewell 1982). Both of these factors can negatively affect incumbency advantages and lead to higher turnover rates in multimember districts.

\section{Literature Reviem and Critique}

The strongest results indicating that district magnitude has a significant effect are found in Rule's study (1987) comparing 23 advanced industrialized democracies. Rule tests a series of institutional, political, social, and cultural variables to see what effect they have on the proportion of women in national legislatures. She finds a strong positive relationship between district magnitude and percent of women legislators in party list PR countries. Engstrom (1987) considers district magnitude and female representation in the Irish Dail. He finds that districts with four or five seats are more likely to have female representatives than districts with only three seats. He suggests that one explanation for the relatively few women in the Irish Dail is that district magnitude is lower than in other PR systems.

The results relating district magnitude to women's representation, however, are far from uniform. Beckwith (1990), in looking at the Italian Chamber of Deputies, finds no relationship between district magnitude and proportion of the delegation which is female for either of the two largest parties, the Communists and the Christian Democrats. Two recent studies looking at the relationship between district magnitude and representation in subnational elections in Great Britain and the United States (district councils in the United Kingdom and state legislatures in the United States) also failed to find a powerful effect of district magnitude on representation (Welch and Studlar 1990; Studlar and Welch 1991).

In sorting out these inconsistent findings, two plausible explanations come to mind. First, there may be institutional reasons why one might find differing 
results. Second, there may be methodological explanations. Let us review both of these possibilities.

There are plausible institutional reasons why the existing research provides an inconsistent picture of district magnitude's effect. The Engstrom study and most of the cases in Rule's data set are from countries which use a PR electoral system, while the Welch and Studlar studies are from the United Kingdom and the United States where, even though the districts are multimember, the election systems differ. Particularly important is the influence of the party leadership on candidate selection. In the United States, that influence is minimal; in Ireland, and most other European countries, party leadership has substantial influence. If, as suggested earlier, one of the crucial factors in the relationship between district magnitude and female representation is a party's desire to balance its ticket, the power to actually balance the ticket is greater in systems where the nomination process is much more closed than the very open process found in the United States.

A second significant institutional difference is that the United Kingdom and United States data are from subnational electoral districts while those studies finding support for the effect of district magnitude are from national legislative assemblies. There are obvious distinctions between the national and the subnational levels. Posts at the subnational level have substantially less prestige than positions in the national legislatures. There is also some tradition within both the United Kingdom and United States for female activism at the local level. These factors may make women's access substantially easier and limit the need for institutional mechanisms to increase representation. Certainly women have had far greater success gaining access to subnational legislatures in the United Kingdom and the United States. Even after recent gains in representation at the national levels, representation at the local level is still more than twice what it is at the national level.

Methodological questions can also be raised regarding previous studies. One concern is that Rule's finding, that district magnitude and proportion female are correlated, may be spurious. The strong effect Rule finds across Western democracies relies heavily on the high level of both district magnitude and female representation in the Scandinavian countries. To the degree that Scandinavian countries have a unique political culture which is especially conducive to women participating in politics, one would expect these countries to have high levels of female representation (Putnam 1976; Norris 1985; see, however, Skard and Haavio-Mannila 1984). Even if district magnitude has no real effect, if Scandinavian political culture has a strong effect, the correlation between district magnitude and percent female will be large and positive. An additional methodological concern is that all the previous studies are cross-sectional. If district magnitude's effect changes over time, the different findings may simple be due to the various countries being at different points on a time continuum.

District magnitude's effect is still an open question. This study helps clarify some of the uncertainty by taking an intensive look at the relationship between district magnitude and female representation in Norway over a 40 -year period. 
TABLE 1

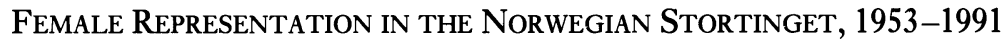

\begin{tabular}{|c|c|c|c|c|c|}
\hline Year & $\begin{array}{c}\text { Number } \\
\text { of Women } \\
\text { MPs }\end{array}$ & $\begin{array}{c}\text { Number } \\
\text { of MPs }\end{array}$ & $\begin{array}{c}\% \text { of } \\
\text { Storting } \\
\text { Female } \\
\end{array}$ & $\begin{array}{c}\text { Correlation } \\
\text { between District } \\
\text { Magnitude and } \\
\text { Female \% } \\
\text { of District } \\
\text { Delegation } \\
\end{array}$ & $\begin{array}{c}\text { Correlation } \\
\text { between } \\
\text { Party Magnitude } \\
\text { and Female \% } \\
\text { of Party District } \\
\text { Delegation } \\
\end{array}$ \\
\hline 1953 & 7 & 150 & $4.7 \%$ & -.05 & $.34^{* *}$ \\
\hline 1957 & 10 & 150 & $6.7 \%$ & .21 & $.45^{* *}$ \\
\hline 1961 & 13 & 150 & $8.7 \%$ & .28 & $.52 * *$ \\
\hline 1965 & 12 & 150 & $8.0 \%$ & $.43^{*}$ & $.32 * *$ \\
\hline 1969 & 14 & 150 & $9.3 \%$ & .36 & $.38 * *$ \\
\hline 1973 & 24 & 155 & $15.5 \%$ & .15 & $.25^{*}$ \\
\hline 1977 & 37 & 155 & $23.9 \%$ & .21 & .20 \\
\hline 1981 & 40 & 155 & $25.8 \%$ & -.04 & $.24^{*}$ \\
\hline 1985 & 54 & 157 & $34.4 \%$ & .02 & .15 \\
\hline 1989 & 59 & 165 & $35.8 \%$ & .30 & .21 \\
\hline
\end{tabular}

${ }^{*}=$ Significant at the .05 level $\left(2\right.$-tailed test); ${ }^{* *}=$ Significant at the .01 level (2-tailed test).

There are strong methodological reasons for studying the effect of district magnitude in one country. By looking at an individual country, political culture is controlled for. ${ }^{2}$ Norway is particularly appropriate for several other reasons. District magnitude varies widely in Norway, from four seats to 16 seats. At $36 \%$, the Norwegian Storting has the second highest level of female representation in the world. It is important to test whether district magnitude may be one of the reasons that Norway has attained its forward position. Finally, because the electoral system has remained stable, it is possible to look at the relationship over a 40 -year period: this enables us to see if district magnitude's effect varies over time.

\section{Data and Methods}

Data were collected for each member of parliament and each electoral district (i.e., each county) for a 40-year period (Nordby 1985; Torp 1978, 1982, 1986, 1990). The period considered, 1953 to 1991 , encompasses 10 parliamentary elections. Changes in election laws make it difficult to consider elections prior to 1953.

Columns 2-5 of table 1 provide data on the number of women in the Storting, the total number of members of parliament, the percentage of the Storting which was female, and the correlation between district magnitude and percent female for

${ }^{2}$ Obviously different political cultures can exist within a country, but the spread in culture is likely to be much less from Kristiansand to Hammerfest than from Hammerfest to Barcelona, Rome, or Athens. 
each of the 10 sessions. $^{3}$ Female representation consistently increases over the 10 Stortings, reaching its high point in 1989 when $35.8 \%$ of the elected representatives were women. The correlation between district magnitude and percent female, however, is statistically significant for only one of the 10 Stortings, 1965. For most of the period there is little relationship and in some cases the relationship is even negative. The initial impression is that district magnitude is not strongly associated with female representation in Norway.

Before rejecting the concept of district magnitude entirely, a revision of the concept should be considered. Darcy, Welch, and Clark (1987) suggest that greater district magnitude will not automatically lead to an increase in female representation. They suggest an interaction between district magnitude and number of parties. Where there is a large district magnitude but many parties are represented, women may have just as difficult a time winning representation as in electoral systems with smaller magnitudes and fewer parties. If each party only expects to win one or two seats, competition for slots at the top of the party list become zero-sum games similar to those fought in single-member districts. It is therefore possible that party magnitude, the number of seats a party has in a district, rather than district magnitude causally affects representation rates.

An initial test of party magnitude's relationship is shown in column 5 of table 1 . For five of the first six elections (the period for which I will argue party magnitude is most crucial) there is higher correlation between party magnitude and the percent of the party district delegation which is female than between district magnitude and the percent of the district delegation which is female. The relationship is statistically significant for all six cases of party magnitude and only once for district magnitude.

To further test the effect of party magnitude, regressions were run for each parliamentary election. The dependent variable is the female percent of party district delegation. When delegations are counted as district and party specific there are between 69 (1977) and 88 (1989) delegations. In the regressions each case is weighted by delegation size. ${ }^{4}$

The crucial independent variable is party magnitude. If my argument is correct, party magnitude should be positively associated with percentage of delegation which is female. In addition, two control variables are included: left party and

${ }^{3}$ In 1973 and 1985 the size of the parliament was increased, first from 150 to 155 members, then to 157 members. Districts which had significantly increased their population were given new seats. In 1989 , the parliament was increased to 165 members as a system of "vote equalization seats" was used for the first time.

${ }^{4}$ For example, a one-member delegation gets a weight of one, while a five-member delegation gets a weight of five. Weighting by delegation size provides an $N$ equivalent to the number of MPs in parliament. As our ultimate concern is with the number of women in parliament, this is the correct weighting procedure. The procedure decreases the standard errors of the regression coefficients. The results of the unweighted regressions have slightly lower $R$-squares and a couple of the coefficients slip from being significant to nonsignificant, but the overall pattern is just as supportive of the theoretical arguments made as the results for the weighted regressions. 
urban district. Leftist parties have been found to be more supportive of female candidates in previous studies (Duverger 1955; Lakeman 1976; Rasmussen 1983; Norris 1987) and urban areas have also been found to be more supportive of female candidates (Matland and Brown 1992; Moncrief and Thompson 1991). Left party is a dummy variable which is 1 when the district delegation is Communist, Labour, Socialist Left, or Socialist People's Party (NKP, DNA, SF/SV). Urban District is an ordinal variable equal to 2 for districts with cities over 250,000 (only Oslo meets this criteria), 1 for districts with cities over 75,000, and 0 otherwise.

The regression results are presented in table 2 and provide strong evidence that all the variables are relevant, but that their effects are distinctly time bound. Urban district has a statistically significant and positive effect for two of the first four elections but then is insignificant in each of the last six elections. Not once in the seven elections held in the 1950s, 1960s, and 1970s were leftist district delegations more favorable toward women. In the 1980s, however, the effect of leftist parties was both statistically and substantively significant. Leftist delegations had $12 \%$ (1981), $14.5 \%$ (1985), and a whopping $23.7 \%$ (1989) more women than the other parties.

Looking at the crucial party magnitude variable, it has a relatively weak effect in 1953 but increases in strength (as indicated by the increase in the size of the unstandardized coefficients) and remains powerful from 1957 through 1973. The effect is most powerful in 1969 where for each unit increase in party magnitude the delegation's percentage of women went up by $4.9 \% .^{5}$ After 1973 , party magnitude weakens in effect and is statistically significant in only one of the last four elections.

\section{Discussion}

These analyses provide a couple of important findings. First, the effect of electoral district size can best be understood by considering party magnitude, rather than merely looking at district magnitude. ${ }^{6}$ The two are clearly related, but just considering district magnitude introduces slippage. Party magnitude is an intervening variable which is causally closer to the dependent variable, but which is obviously affected by district magnitude. In most cases, the correlation between party magnitude and district magnitude is strong. If the correlation is strong,

\footnotetext{
${ }^{5}$ Party magnitude varies in size from one (the most common) to seven-member delegations. The units being dealt with here are not continuous, but discrete. Obviously a coefficient of 4.90 cannot mean that when a delegation increases from one member to two members that it would go from having 0 women to have $1 / 10$ th of a woman. What it does mean is that for a large sample of two-member delegations there would be about $5 \%$ more women than a sample of single-member districts of the same size.

${ }^{6}$ In a separate test comparing the explanatory effects of district magnitude and party magnitude, regressions were run with the female percent of the district delegation as the dependent variable, testing district magnitude in one set of regressions and replacing district magnitude with two-party magnitude (which measured the number of seats won by the two largest parties) as a modified party magnitude measure in the other set of regressions. Two-party magnitude clearly outperformed district magnitude. In all 10 elections the equation using two-party magnitude explained more of the variance and two-party magnitude was statistically significant nearly twice as often as district magnitude.
} 
TABLE 2

Regression Results: Female Percentage of Party District Delegation as Dependent Variable, 1953-1989¹

\begin{tabular}{|c|c|c|c|c|c|c|c|c|c|c|}
\hline Year & 1953 & 1957 & 1961 & 1965 & 1969 & 1973 & 1977 & 1981 & 1985 & 1989 \\
\hline \multirow[t]{2}{*}{ Constant } & -.43 & -3.28 & $-3.93^{*}$ & -3.04 & $-4.31^{*}$ & 4.17 & $15.27 * *$ & $11.52 * *$ & $23.22^{* *}$ & $17.23^{* * *}$ \\
\hline & $(1.68)$ & $(1.78)$ & $(1.94)$ & $(2.14)$ & $(2.09)$ & $(3.25)$ & $(3.66)$ & $(3.73)$ & $(4.05)$ & $(4.47)$ \\
\hline \multirow[t]{2}{*}{ Party Magnitude } & $1.34 *$ & $2.39 * *$ & $3.23 * *$ & $3.23 * *$ & $4.91^{* *}$ & $3.95 * *$ & 1.38 & $3.48 * *$ & 1.61 & 1.44 \\
\hline & $(.67)$ & $(.77)$ & $(.87)$ & $(1.02)$ & $(1.02)$ & $(1.44)$ & $(1.38)$ & (1.19) & $(1.25)$ & $(1.76)$ \\
\hline \multirow[t]{2}{*}{ Left Party } & .43 & 1.82 & 4.72 & 2.30 & -1.12 & 2.13 & 3.58 & $12.12 * *$ & $14.45^{* *}$ & $23.71 * *$ \\
\hline & (2.34) & $(2.65)$ & $(2.70)$ & $(3.03)$ & (3.27) & (3.79) & $(4.64)$ & $(3.54)$ & $(4.05)$ & $(4.80)$ \\
\hline \multirow[t]{2}{*}{ Urban District } & 2.37 & $4.79 * *$ & 2.37 & $3.84 *$ & -.03 & .68 & 4.38 & -4.27 & -2.51 & 5.87 \\
\hline & $(1.34)$ & (1.49) & (1.59) & $(1.91)$ & $(1.83)$ & (2.79) & $(3.23)$ & $(2.76)$ & $(3.12)$ & $(3.62)$ \\
\hline Adjusted $R$-squared & .07 & .24 & .29 & .21 & .27 & .08 & .04 & .15 & .11 & .18 \\
\hline$N$ & 74 & 72 & 74 & 80 & 77 & 86 & 69 & 70 & 70 & 88 \\
\hline Weighted $N$ & 150 & 150 & 150 & 150 & 150 & 155 & 155 & 155 & 157 & 165 \\
\hline
\end{tabular}

${ }^{*}=$ Significant at the .05 level (2-tailed test) ${ }^{* *}=$ Significant at the .01 level (2-tailed test).

${ }^{1}$ Unstandardized regression coefficients reported in table. Standard errors are in parentheses. 
when district magnitude increases the number of seats won by the largest parties increases and the number of parties with multiple seats increases; both of these provide greater opportunities for women to be elected. If the correlation is low, however, increased district magnitude need not lead to increased representation of women, instead it may lead to increases in representation of small parties with one-member delegations. Under these conditions there will be only a weak correlation between district magnitude and female representation. In short, while district magnitude's effect on female representation can vary, party magnitude's effect is more consistently positive.

The second finding is that party magnitude's effect on female representation, occurs for only a limited time period. Party magnitude's effect follows a cycle. Initially, there is a weak effect which strengthens over time. Once women are well established within the parties, however, party magnitude's effect diminishes and is unimportant.

As the focus shifts from district magnitude to party magnitude, the need to consider parties more carefully becomes obvious. Specifically, candidate selection procedures loom as a factor of considerable importance. By carefully considering the interaction between candidate selection and party magnitude, a clearer picture of party magnitude's effect on female representation in Norway can be developed. In doing so, a more general understanding of how party magnitude affects representation can also be established.

\section{Candidate Selection Processes}

Norwegian elections, as most party list electoral systems, are first and foremost competitions between parties and not between individual candidates. Valen (1988) reports that in a national survey, $33 \%$ of respondents were unable to name a single Storting candidate in their district, $28 \%$ were able to name one or two, and only $39 \%$ were able to name three or more. Campaigns focus on national party leaders and policies formulated by the national party; individual candidates can only to a very limited degree influence their election results. In addition, for most of the post-World War II period Norwegian politics has seen only very small voter movement from one election to another. Parties could predict, with a high degree of certainty, how many representatives they would win and in what districts. Under these conditions, the party nomination processes become crucial to an individual candidate's likelihood of becoming a member of the Storting.

The list of candidates running in each county is promulgated by the county party organizations. The national party provides guidelines, but they have no veto power over candidates (Valen 1988). The process is similar in all parties and is governed by the Act of Nominations, a law passed in 1921. A county nominating committee, composed of 5-15 county party leaders, receives suggestions, proposals, and generally a rank ordering of possible candidates from local party organizations. Based on these recommendations and their own evaluations, the county 
nominating committee proposes a slate of candidates and alternates, with rank ordering of candidates. This proposal is presented to the county nominating convention where the final decisions are made on the county party's Storting list. The county conventions are usually all-day sessions. Delegates are elected from local party organizations and must be dues-paying party members. The most common outcome is that the nominating committee's proposal is accepted with only minor changes. It is not unusual, however, for a county nominating convention to change the rank ordering of candidates, propose new candidates, or even reject the committee's top candidate.

Valen (1988) describes the Norwegian nomination process as one of decentralized group representation. Decentralization refers to the local county party organizations control over nominations. Group representation refers to the importance of having a base in interests which a party aspires to represent. Descriptive representation posits that for effective representation delegates must have the characteristics of the groups they are to represent (Pitkin 1967). This concept is strongly imbedded in Norwegian parties and is taken very seriously as a legitimate principle of representation, as a method of integrating party factions and thereby maintaining party peace, and as a manner in which to maximize the party's appeal to voters (Valen 1966). A candidate's chances are substantially strengthened if the candidate is associated with and draws support from groups perceived of as having a legitimate demand for representation. The relevant interests vary across the parties. Traditionally, geographical considerations and occupational groupings have been central considerations in all parties (Valen 1956, 1966, 1988). In addition, support from various cultural and issue-specific groups tied to a party are important. The story of women's rise in Norwegian national politics is one of changes in their position in this ticket balancing puzzle. In 40 years they have moved from a position of irrelevance and peripheral status to one of the central considerations in composing a party's slate.

\section{Changing Patterns of Female Representation}

While the institutional framework has remained stable, there have been large changes in female representation. These changes are directly tied to changes in the position and legitimacy of women candidates within the county nominating conventions. Female representation in the Norwegian Storting can be split into four time periods: 1909-1953, 1957-1973, 1977-1981, 1985 to present. In each of these time periods, there are distinct patterns. A description of each period follows.

1909-1953: Giants among Men. From the time women gained the right to vote in 1909 to 1953 there were 16 women who served in the Storting (Means 1973). They were able to win positions at a time when politics was dominated by men. These unique women, giants if you will, are not easily predicted, although some 
patterns appear. During this time period party magnitude had an effect, almost all of these women were elected in districts where their party had at least three seats (Aasland 1964). The effect, however, is a very weak one. Party magnitude's regression coefficient in 1953 indicates that when party magnitude increases by one the female delegation percentage increases by only $1.3 \%$. Large district delegations are effectively a necessary, but not a sufficient condition for female representation in this era. Where there was a woman MP there was likely to be a large party district delegation. Where there were large party district delegations, however, there was no certainty of finding a female representative. Another pattern is that the earliest representatives tended to come from the cities. The historical data show that while Oslo has been about $10 \%$ of the country's population, during this first period more than $30 \%$ of the female representatives came from Oslo.

Valen (1966) surveyed over 100 party leaders in the seven largest parties in Rogaland county in 1957. In describing what qualifications were important for parliamentary candidates, Labour Party respondents emphasized being active in and loyal to the Labour Party. Within the nonsocialist parties' emphasis was placed on having a position of standing within the local community. This usually referred to an important occupational position, previous experience in public office, or activity in social organizations outside of the party. In $1957,89 \%$ of the Storting members had served as members of local municipal councils. In 1955 , however, only $6.4 \%$ of local council representatives were female (Central Bureau of Statistics 1980). Throughout this first era and into the second, substantially lower labor force participation rates, lower levels of education, limited experience in local government and in other social organizations, provided women with a distinct disadvantage.

1957-1973: One Is Enough. Means (1972) interviewed 15 of the 16 female representatives serving in the Storting in 1970 regarding their recruitment. She quotes extensively from her interviews and one of the most telling conversations follows:

$\mathrm{Oh}$, the old male attitudes are still with us! We aren't free of them yet. All the parties preach loudly about recruiting more women, but when the actual recruitment begins, it is still the case that they tend to consider only men. And then suddenly someone remembers: "By Jove, we haven't got a woman! Let's find a woman!" But one is enough - that will suffice.

One is enough describes this era well. In this time period only one district party delegation had more than one woman, the exception was the Oslo Labour party. While the pressure exerted to increase female representation resulted in some increase, representation was far from equal. Nevertheless, female representation gradually rose throughout this period from $8 \%$ in 1957 to $15.5 \%$ in 1973 .

In the previous period, women were elected in spite of being women. By the 1960 s, the women's movement started making significant inroads at the local political level and in public debate. Women's auxiliaries of the parties turned from seeing their interests in terms of party success to also seeing an interest in being represented. In 1971, there was an active campaign to get women to vote for female 
candidates at the local level which provided a shock when women suddenly moved from approximately $20 \%$ of the city council to a majority in several major cities including the capitol, Oslo (Bystydzienski 1988). ${ }^{7}$ In this second period, women became an organized and legitimate interest; one which parties had to consider in developing their party lists. One indication of this is that by 1973 all district party delegations of four representatives or more had a woman in the delegation.

While women as a group became seen as a legitimate interest, they were not a strong interest. It is exactly under these conditions that party magnitude plays a role. A party will satisfy the more powerful interests first and move on to weaker interests second. If the party has several seats then those legitimate, but weaker, interests will be represented. If the party has few seats, the party's quota will be used up before those weaker interests have made it to parliament. The regressions, in table 2 , reinforce this point; party magnitude was statistically and substantively significant precisely during this time period.

The Storting representatives Means (1973) interviewed strongly believed that women candidate's inability to draw support from the traditionally powerful groups within their parties was their most important handicap. At the same time, several of these women said that being a woman had been an advantage in their own case. Especially among the nonsocialist parties, women with relatively little political experience were placed high up on their party's list. While this may seem contradictory, it is easily explained by the words used to describe this period, one is enough. Women could expect to receive some representation under the existing rules, but if they were to increase their representation they would have to be seen not as female representatives, but as representatives of other more powerful interests within the parties.

1977-1981: Tokenism No More. The Storting representatives Means interviewed believed women needed to become the candidate of the powerful groups within the parties. An alternative, not emphasized by her respondents, was for women to move from a position of being one of several peripheral interests to being a central interest and finally to institutionalizing demands for gender equality. Moves in this direction occurred in the late 1970s. The election results from 1977 show several significant trends. First, representation jumped from $15.5 \%$ to $23.6 \%$. Second, for the first time there were party district delegations, other than the Oslo Labour party, which had more than one woman. The number of party district delegations with more than one woman jumped from one in 1973 to seven in 1977, striking evidence that the period of "one is enough" was over. By 1977, party magnitude is also no longer statistically significant in the regression equations.

In 1977, both the Liberal and Socialist Left parties endorsed affirmative action plans to insure that $50 \%$ of their candidates were female. The substantive effects

${ }^{7}$ Local elections are also party-list elections, but at the local level voters are allowed to strike names, add names, and to cumulate their votes for one candidate on the list. By systematically urging women to strike all the male names from their party's list, the surprising results of the "women's coup" were created. 
of these actions were extremely limited since the Liberals and Socialist Left won only four seats in the 155 member Storting in 1977. The symbolic effect was, however, significant. The Socialist Left in particular plays an important role in Norwegian politics trying to push the Labour party to the left. The Labour party needs to be conscious of possible defections to the Socialist Left party. By taking an aggressive stand on the issue of candidate quotas, along with several other issues promoted by feminists, the Socialist Left added additional pressure to that already coming from women's groups within the Labour party.

1985-1989: Gender Equality 7ust around the Corner? In this period, representation increased to $34.4 \%$ in 1985 and to $35.8 \%$ in 1989 . In 1983 , a crucial event occurred; the Norwegian Labour party endorsed an affirmative action proposal to insure that at least $40 \%$ of its candidates were female. This rule change, while merely a guideline for county nominating conventions, has had a strong and rapid effect on the composition of the Labour party parliamentary delegation. In 1981, women constituted 33\% of the Labour party delegation; by 1989 they were in the majority: $51 \%$ of the parliamentary delegation was female. Labour's undisputed position as the largest party in Norwegian politics has made this an especially significant event. Even though only one party has explicitly adopted an affirmative action plan after Labour's decision, the decision has strengthened women activists in all the other parties, and there is a clear increase in female representation in all parties, except the Progress party. ${ }^{8}$ The move to institutionalized affirmative action rules within the Socialist Left and Labour party has meant that for the first time, leftist parties exhibit a statistically significant effect on delegation make up. Party magnitude on the other hand is no longer significant by this time period.

The 1989 elections are especially significant in that representation increased in spite of a tremendous jump in support for the Progress party, which is on the far right of Norwegian politics. The Progress party went from $3.8 \%$ of the vote and two representatives in the 1985 Storting to $13 \%$ of the vote and 22 representatives in the 1989 Storting. Of their 22 representatives only one was female. ${ }^{9}$ This means that $4.5 \%$ of the Progress party's parliamentary delegation is female, while $40.5 \%$ of the rest of the Storting is female.

While significant increases in female representation have occurred, complete equality has not been achieved. Incumbency has led to a lag in the invoking of equality rules. Rules on gender equality have been bent for existing (male) incumbents. Turnover rates are, however, fairly high in the Norwegian Parliament; incumbents have returned at a rate of only $60 \%$ to $67 \%$ for the past 25 years (Torp 1990). Therefore, incumbency's effect as a brake on equality should be relatively short lived.

\footnotetext{
${ }^{8}$ In an earlier era, Valen $(1966,131)$ noted a similar trend. He states, "In several constituencies the parties have been slow in nominating women, but when one party nominates a woman all other parties react by following the example."

${ }^{9}$ That one representative was Inger-Marie Ytterhorn, she is the widow of Bjørn Erling Ytterhorn who had been one of the two Progress party representatives in the 1985 parliament.
} 
The position of the Progress party is likely to be a more serious brake on equality. The party is likely to continue to have a sizable parliamentary delegation. It has shown no interest in proactive arrangements to increase the number of women in its parliamentary ranks. In addition, its voters are overwhelmingly male, $69 \%$ in $1985,65 \%$ in 1989 (Valen, Aardal, and Vogt 1990), many of whom have extremely traditional views of the role of women. While the Progress party may elect an occasional female representative there is little reason to expect substantial female representation in the Progress party delegation.

Women's position in the mainstream parties, at this time, can perhaps be described best as "second among equals." If there is a possibility for an even division, that route is usually taken. Among the two-member delegations for example, if one excludes those where two male incumbents or Progress party representatives were elected, in the remaining two-member delegations (14 delegation totaling $28 \mathrm{MPs}$ ) exactly half the representatives are women and half are men, the five four-member delegations are also evenly split between men and women. If an even split is not possible, however, men still tend to come first. For example, six of the seven three-member delegations are two men and one woman. Men enjoy a wide advantage as the number one candidate for most parties, and women are most poorly represented in the one-person delegation. ${ }^{10}$

\section{Discussion}

In reviewing this 40 -year advance from limited to broad representation, the obvious question is why did it happen here? The answer is partly cultural, but primarily institutional. The political institutional arrangements, especially the candidate selection system, were ideal for effective change to occur. In addition, many Norwegian feminists made a conscious decision to use an inside strategy, working within the existing political parties and institutional rules. ${ }^{11}$ Because Norwegian elections are primarily party and not candidate oriented, the real battle for representation occurs at the county nominating conventions. These are limited access affairs dominated by political elites. ${ }^{12}$ This elite may be more sympathetic to demands for greater representation than the public as a whole. Therefore, it may be

${ }^{10}$ These 1989 numbers probably overstate the degree to which women are second among equals. This is because incumbency effects influence these numbers and incumbents are predominantly male. For example, while six of seven 3-member delegations have two men and one women, in four of those delegations there were two male incumbents. It is too early to be able to tell whether true equality well be reached after incumbency effects work themselves out or whether "second among equals" will continue to describe the situation of women in Norwegian parties.

"An example of an outside strategy is the Women's party in Iceland. This party was started due to dissatisfaction with the mainstream parties. It has received substantial publicity and is represented in the Allting, but in taking an outside strategy the women's movement within other parties may have been weakened. Iceland has the lowest level of female representation in parliament among the Nordic countries.

${ }^{12}$ While $80 \%-85 \%$ of the Norwegian public votes in parliamentary elections, only $0.6 \%$ of the public participates in county nominating meetings (Valen 1988). 
easier to establish equal representation principles when only elites need to be convinced. Perhaps more important than an "enlightened" elite, however, is the institutional system which limits access but does not deny it. In such a system, outcomes can come down to pure power politics, where the ability to pack a county convention with pro-women delegates can carry the day. The access threshold is high enough that only highly motivated actors participate, yet low enough that concerted actions are a plausible threat. The threat of packing the convention, defecting to another party (especially salient for the Labour party visa-vis the Socialist Left), or simply sitting out an election can be significant enough that in discussions prior to the county convention, i.e., the nominating board meetings where the initial list is proposed, a compromise solution can be reached.

Over time the compromise solution gradually changed. In the 1960s, the idea of "some" representation became a legitimate concern. The 1970s saw a transition as demands for more equal representation were made and, finally, the 1980s saw that demand accepted. The crucial factor is that the decisions controlled by the party have clear and immediate effects on representation. After the Labour party's 1983 advisory rule on equal representation, female representation climbed from $33 \%$ to $51 \%$ in only two elections.

A couple of interesting contrasts illustrate the importance of institutional arrangements and simultaneously help to explain why a cultural explanation is insufficient. Norwegian women have made substantial progress toward equality in the Storting. In the Norwegian labor movement and in managerial positions in private industry, however, women are in very weak positions (Skjeie 1991). Barely $10 \%$ of the top trade union congress officials are female, despite $40 \%$ of the rankand-file being female. The number of women in top managerial positions in private industry is even less.

These facts have lead some researchers to suggest a "shrinking institutions" argument, which holds that women are given access to the political process, because power is being transferred elsewhere (Holter 1981). Men are consciously not entering politics, because real power resides in other spheres, primarily business. The increase in women in politics is effectively occurring by default. In a country where more than $50 \%$ of GNP flows through the public sector, the idea that the political system has little power seems suspect at the outset. Far more plausible is a comparative institutions explanation. The selection of candidates for parliament is open to public scrutiny with an access structure which allows influence from outside interests. Parties also face a strongly competitive environment where failure to react to demands for action can result in defections. Many of the same interests which have been so successful at changing the face of political representation have tried mightily, but with little success, to influence the advancement of women in private firms and labor union leadership. For private firm advancement, attempts at opening this process up to scrutiny have been rebuffed as unacceptable meddling. While the trade union congress has been somewhat more open, there have been very few concessions. Part of the explanation for this intransigence is that the 
trade union congress maintains a preeminent position as the representative of workers: union officials can afford to alienate some members, because it has little consequence for the trade union congress's position in the corporatist structure (Skjeie 1991).

\section{SUMMARY}

This article started by considering the effect of district magnitude. I argued that simply considering the effect of district magnitude was incomplete; one must also consider party magnitude. The crucial factor is not how many seats there are in the district, but the number of seats a party has to divide among the various intraparty interests and how many parties have multiple-seat delegations. These are likely to increase with district magnitude, but the connection is not automatic.

Party magnitude's influence on female representation is not constant; its effect will depend on the political environment. Party magnitude has its greatest influence when agitation for greater representation has a base but is not firmly established. In this time period, roughly 1957-1973 in Norway, women's probability of being represented clearly increases as a party increases its seats per district. Prior to the late 1950s, female representation was not a political issue. In that environment, the institutional mechanism has little or no effect. By 1977, women have become sufficiently well established that party magnitude is no longer significant. Women are a major political force in even the smallest districts.

Hypothesizing that party magnitude's positive effect is limited to a period of women establishing themselves as a political force helps explain the contradictory findings in the literature. In most western democracies, women are active but have not become institutionalized as a major political force. Under these conditions one would expect a positive effect of district magnitude as reported by Rule (1987) in her multicountry study and as Engstrom (1987) found in his study of Ireland. On the other hand, once women have become firmly established as a legitimate force, party magnitude diminishes in importance. By the time female representation broke the $20 \%$ barrier in Norway, for example, party magnitude had ceased to have an effect. Interestingly, women made up $20 \%$ of the British district councils considered by Welch and Studlar (1990). Their results may be an indication that local-level British politics has gone beyond the stage at which district magnitude is relevant. Beckwith's (1990) results from the Italian Chamber of Deputies remind us party selection processes can vary widely between parties in the same country. She found no relationship between district magnitude and proportion of women for either the Communists or the Christian Democrats. The Communists see themselves as closely aligned with women, and women play a major role in the party; with $24 \%$ of their parliamentary delegation being female they are probably past the stage at which party magnitude matters. For the Christian Democrats, on the other hand, only $4 \%$ of their MPs are female. They are dominated by very 
traditional male networks. They probably have not reached the stage at which female representation is seen as a legitimate interest.

As party magnitude's significance became apparent, attention turned to the role played by the parties and the internal party nominating processes. In Norway, this process is of substantial significance because it is directly linked to who serves in the legislature. The system of county nomination meetings is sufficiently open to allow organized interests to enter. At the same time the system is sufficiently closed and small enough that a cohesive, well-organized interest can have substantial influence on the choice of candidates, even if they only represent an intense minority within the population as a whole.

A number of research questions remain. Individual country historical tests would be useful to determine whether party magnitude exhibits the same pattern as found in Norway. Expanding consideration of party magnitude to groups which have been traditionally underrepresented, other than women, would also be useful. Even if party magnitude has a relatively transitory effect for representation of women, it may have a more permanent effect for representation of other traditionally underrepresented groups, in particular ethnic minorities.

For those concerned with representation of women, a careful consideration of the nomination processes across countries would be an especially fruitful direction for further research. Among the questions deserving further consideration are: Does a relatively closed or an open candidate selection process provide the best chance at equalization? and Is a centralized or a decentralized candidate selection process most likely to bring about equitable representation of women? While research over the past decade has made substantial progress in identifying important institutional variables which influence representation, there remains an extensive amount of research to be completed identifying exactly how the various institutional factors interact with each other and the political environment to help determine female representation in national legislatures.

Manuscript submitted 2 October 1991

Final manuscript received 3 December 1992

\section{REFERENCES}

Aasland, Tertit. 1964. "Women in the Storting." In The Norwegian Storting through 150 Years [in Norwegian], ed. A. Kaartvedt. Vol. 4. Oslo, Norway: Gyldendal Forlag.

Beckwith, Karen. 1990. "District Magnitude and the Nomination and Election of Women to Parliament." College of Wooster. Manuscript.

Bystydzienski, Jill. 1988. "Women in Politics in Norway." Women and Politics 8:73-95.

Castles, Francis. 1981. "Female Legislative Representation and the Electoral System." Politics $1: 21-26$.

Central Bureau of Statistics of Norway. 1980. Municipal Elections 1979. Oslo, Norway: Central Bureau of Statistics Press. 
Darcy, Robert, Susan Welch, and Janet Clark. 1987. Women, Elections, and Representation. New York: Longman Press.

Duverger, Maurice. 1955. The Political Role of Women. Paris: UNESCO.

Engstrom, Richard. 1987. "District Magnitude and the Election of Women to the Irish Dail." Electoral Studies 6:123-32.

Grofman, Bernard, and Arend Lijphart, eds. 1986. Electoral Laws and Their Political Consequences. New York: Agathon Press.

Holter, Harriet. 1981. "On Female Suppression, Men's Suppression, and Techniques of Rule." In The Face of Power [in Norwegian], ed. T. Andenaes. Oslo, Norway: Gyldendal Forlag.

Inter-Parliamentary Union. 1992. Women and Political Power. Geneva: IPU.

Jewell, Malcolm. 1982. Representation in State Legislatures. Lexington, KY: University Press of Kentucky.

Kirkpatrick, Jeane. 1974. Political Women. New York: Basic Books.

Lakeman, Enid. 1976. "Electoral Systems and Women in Parliament." Parliamentarian 56:159-62.

Lijphart, Arend. 1985. "The Field of Electoral Systems Research: A Critical Survey." Electoral Studies $4: 3-14$.

Matland, Richard E., and Deborah Dwight Brown. 1992. "District Magnitude's Effect on Female Representation in State Legislatures." Legislative Studies Quarterly 17:469-92.

Means, Ingunn Norderval. 1972. "Political Recruitment of Women in Norway." Western Political Quarterly 25:491-521.

Means, Ingunn Norderval. 1973. Women in Norwegian Politics [in Norwegian]. Oslo, Norway: Cappelens Forlag.

Moncrief, Gary F., and Joel A. Thompson. 1991. "Urban and Rural Ridings and Women in Provincial Politics in Canada: A Research Note on Female MLAs." Canadian Fournal of Political Science 24:831-37.

Nordby, Trond. 1985. Storting and the Government, 1945-1985: Institutions and Recruitment [in Norwegian]. Oslo, Norway: Kunnskapsforlaget.

Norris, Pippa. 1985. "Women's Legislative Participation in Western Europe." Western European Politics 8:90-101.

Norris Pippa. 1987. Politics and Sexual Equality. Boulder, CO: Rienner.

Pitkin, Hanna. 1967. The Concept of Representation. Berkeley, CA: University of California Press.

Putnam, Robert. 1976. The Comparative Study of Political Elites. Englewood Cliffs, NJ: Prentice-Hall.

Rasmussen, Jørgen. 1983. "Women's Role in Contemporary British Politics: Impediments to Parliamentary Candidature." Parliamentary Affairs 36:300-16.

Rule, Wilma. 1981. "Why Women Don't Run: The Critical Contextual Factors in Women's Legislative Recruitment." Western Political Quarterly 34:60-77.

Rule, Wilma. 1987. "Electoral Systems, Contextual Factors and Women's Opportunity for Election to Parliament in 23 Democracies." Western Political Quarterly 40:477-98.

Skard, Torild, and Elina Haavio-Mannila. 1984. "Equality between the Sexes-Myth or Reality in Norden?" Daedalus 113:141-67.

Skjeie, Hege. 1991. "A Tale of Two Decades: The Ending of Male Political Hegemony." Institutt for Samfunnsforskning, Oslo, Norway. Manuscript.

Studlar, Donley T., and Susan Welch. 1991. "Does District Magnitude Matter? Women Candidates in Local London Elections." Western Political Quarterly 44:457-66.

Taagepera, Rein, and Matthew Soberg Shugart. 1989. Seats and Votes: The Effects and Determinants of Electoral Systems. New Haven, CT: Yale University Press.

Torp, Olaf Chr. 1978. Stortinget: In Name and Number: 1977-1981 [in Norwegian]. Oslo, Norway: Universitetsforlaget.

Torp, Olaf Chr. 1982. Stortinget: In Name and Number: 1981-1985 [in Norwegian]. Oslo, Norway: Universitetsforlaget.

Torp, Olaf Chr. 1986. Stortinget: In Name and Number. 1985-1989. (in Norwegian) Oslo, Norway: Universitetsforlaget. 
Torp, Olaf Chr. 1990. Stortinget: In Name and Number: 1989-1993 [in Norwegian]. Oslo, Norway: Universitetsforlaget.

Valen, Henry. 1956. "Nominations for Storting Elections" [in Norwegian]. Statsøkonomisk Tidskrift 70:115-42.

Valen, Henry. 1966. "The Recruitment of Parliamentary Nominees in Norway." Scandinavian Political Studies 1:121-66.

Valen, Henry. 1988. "Norway: Decentralization and Group Representation." In Candidate Selection in Comparative Perspective: The Secret Garden of Politics, ed. Michael Gallagher and Michael Marsh. London: Sage.

Valen, Henry, Bernt Aardal, and Gunnar Vogt. 1990. Change and Continuity: The Storting Election of 1989 [in Norwegian]. Sosiale og Økonomiske Studier 74, Oslo, Norway: Statistisk Sentralbyrå.

Welch, Susan, and Donley T. Studlar. 1990. "Multi-Member Districts and the Representation of Women: Evidence from Britain and the United States." The Fournal of Politics 52:391-412.

Richard E. Matland is assistant professor of political science, University of Houston, Houston, TX 77204-3474. 
http://www.jstor.org

\title{
LINKED CITATIONS
}

- Page 1 of 2 -

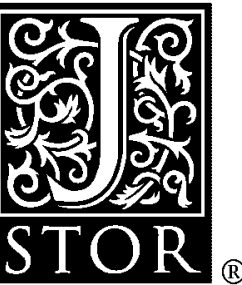

You have printed the following article:

Institutional Variables Affecting Female Representation in National Legislatures: The Case of Norway

Richard E. Matland

The Journal of Politics, Vol. 55, No. 3. (Aug., 1993), pp. 737-755.

Stable URL:

http://links.jstor.org/sici?sici=0022-3816\%28199308\%2955\%3A3\%3C737\%3AIVAFRI\%3E2.0.CO\%3B2-2

This article references the following linked citations. If you are trying to access articles from an off-campus location, you may be required to first logon via your library web site to access JSTOR. Please visit your library's website or contact a librarian to learn about options for remote access to JSTOR.

\section{References}

District Magnitude's Effect on Female Representation in U. S. State Legislatures

Richard E. Matland; Deborah Dwight Brown

Legislative Studies Quarterly, Vol. 17, No. 4. (Nov., 1992), pp. 469-492.

Stable URL:

http://links.jstor.org/sici?sici=0362-9805\%28199211\%2917\%3A4\%3C469\%3ADMEOFR\%3E2.0.CO\%3B2-M

\section{Political Recruitment of Women in Norway}

Ingunn Norderval Means

The Western Political Quarterly, Vol. 25, No. 3. (Sep., 1972), pp. 491-521.

Stable URL:

http://links.jstor.org/sici?sici=0043-4078\%28197209\%2925\%3A3\%3C491\%3APROWIN\%3E2.0.CO\%3B2-T

\author{
Why Women Don't Run: The Critical Contextual Factors in Women's Legislative \\ Recruitment \\ Wilma Rule \\ The Western Political Quarterly, Vol. 34, No. 1, Special Issue on Women and Politics. (Mar., 1981), \\ pp. 60-77. \\ Stable URL: \\ http://links.jstor.org/sici?sici=0043-4078\%28198103\%2934\%3A1\%3C60\%3AWWDRTC\%3E2.0.CO\%3B2-L
}


http://www.jstor.org

\section{LINKED CITATIONS \\ - Page 2 of 2 -}

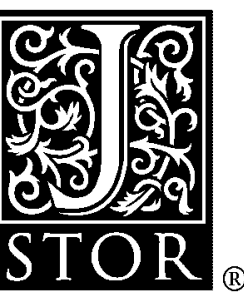

Electoral Systems, Contextual Factors and Women's Opportunity for Election to Parliament in Twenty-Three Democracies

Wilma Rule

The Western Political Quarterly, Vol. 40, No. 3. (Sep., 1987), pp. 477-498.

Stable URL:

http://links.jstor.org/sici?sici=0043-4078\%28198709\%2940\%3A3\%3C477\%3AESCFAW\%3E2.0.CO\%3B2-R

Does District Magnitude Matter? Women Candidates in London Local Elections

Donley T. Studlar; Susan Welch

The Western Political Quarterly, Vol. 44, No. 2. (Jun., 1991), pp. 457-466.

Stable URL:

http://links.jstor.org/sici?sici=0043-4078\%28199106\%2944\%3A2\%3C457\%3ADDMMWC\%3E2.0.CO\%3B2-Z

Multi-Member Districts and the Representation of Women: Evidence from Britain and the United States

Susan Welch; Donley T. Studlar

The Journal of Politics, Vol. 52, No. 2. (May, 1990), pp. 391-412.

Stable URL:

http://links.jstor.org/sici?sici=0022-3816\%28199005\%2952\%3A2\%3C391\%3AMDATRO\%3E2.0.CO\%3B2-6 